\title{
Ethanol Potentiation of GABAergic Synaptic Transmission May Be Self-Limiting: Role of Presynaptic $\mathrm{GABA}_{\mathrm{B}}$ Receptors
}

\author{
Olusegun J. Ariwodola and Jeffrey L. Weiner \\ Department of Physiology and Pharmacology, Wake Forest University School of Medicine, Winston-Salem, North Carolina 27157
}

Ethanol enhances GABAergic synaptic inhibition, and this interaction contributes to many of the behavioral and cognitive effects of this drug. Most studies suggest that ethanol enhances GABAergic neurotransmission via an allosteric potentiation of the postsynaptic $\mathrm{GABA}_{\mathrm{A}}$ receptors that mediate fast synaptic inhibition in the mammalian CNS. Despite widespread acceptance of this hypothesis, direct support for such a mechanism has been difficult to obtain. Ethanol does not enhance $\mathrm{GABA}_{\mathrm{A}}$ receptor function in all brain regions or under all experimental conditions, and factors responsible for this variability remain mostly unknown. Notably, blockade of $G_{A B A_{B}}$ receptors dramatically enhances ethanol potentiation of hippocampal GABA ${ }_{\mathrm{A}}$ IPSPs and IPSCs, suggesting that some unknown $\mathrm{GABA}_{\mathrm{B}}$ receptor mechanism limits the overall potentiating effect of ethanol on GABAergic synapses. In this study, we demonstrate that, at perisomatic synapses in the rat hippocampus, ethanol enhances presynaptic $\mathrm{GABA}_{\mathrm{B}}$ autoreceptor function and that this interaction reduces the overall potentiating effect of ethanol at these synapses. We further show that ethanol significantly elevates basal presynaptic $\mathrm{GABA}_{\mathrm{B}}$ receptor tone, possibly via an increase in spontaneous GABA release, and that pretreatment with a subthreshold concentration of the $\mathrm{GABA}_{\mathrm{B}}$ receptor agonist baclofen blocks ethanol but not flunitrazepam or pentobarbital potentiation of $\mathrm{GABA}_{\mathrm{A}} \mathrm{IPSC}$. These data suggest that an interaction between ethanol and presynaptic $\mathrm{GABA}_{\mathrm{B}}$ autoreceptor activity regulates the ethanol sensitivity of GABAergic synapses. Given that the in vitro ethanol sensitivity of these synapses correlates with in vivo ethanol responsiveness in a number of rodent lines, our data further suggest that presynaptic $\mathrm{GABA}_{\mathrm{B}}$ receptor activity may play a role in regulating behavioral sensitivity to ethanol.

Key words: alcohol; GABA; hippocampus; IPSP; patch clamp; slice

\section{Introduction}

Alcohol addiction remains an imposing medical and socioeconomic concern for many nations (Volpicelli, 2001). For example, in the United States, alcoholism and alcohol abuse rank among the top three psychiatric illnesses (Kessler et al., 1994). In addition, alcohol-related disorders are responsible for $>105,000$ deaths annually in the United States (McGinnis and Foege, 1999) at a cost of $>150$ billion dollars. Despite these staggering statistics, the neurophysiological mechanisms that mediate alcohol intoxication, reinforcement, and dependence are not fully understood. A hypothesis that has received increasing support over the past 20 years is that alcohol interacts with a subset of neuronal proteins that control excitatory and inhibitory synaptic communication in the CNS (Deitrich et al., 1989; Faingold et al., 1998). In particular, much attention has focused on the acute potentiating effects of alcohol on inhibitory synaptic transmission mediated by $\mathrm{GABA}_{\mathrm{A}}$ receptors.

$\mathrm{GABA}_{\mathrm{A}}$ receptors mediate the majority of fast inhibitory synaptic transmission in the mammalian CNS (Krnjevic, 1991;

\footnotetext{
Received May 7, 2004; revised 0ct. 15, 2004; accepted 0ct. 15, 2004.

This work was supported by National Institutes of Health Grants AA 013960 and AA 011997. We thank Drs. Mario Carta, Brian McCool, and Fernando Valenzuela for helpful comments on this manuscript.

Correspondence should be addressed to Dr. Jeff L. Weiner, Department of Physiology and Pharmacology, Wake Forest University School of Medicine, Medical Center Boulevard, Winston-Salem, NC 27157. E-mail: jweiner@wfubmc.edu.

DOI:10.1523/JNEUROSCI.1768-04.2004

Copyright $\odot 2004$ Society for Neuroscience $\quad$ 0270-6474/04/2410679-08\$15.00/0
}

Thompson, 1994). These receptors serve as the primary target for a variety of sedative and hypnotic drugs, such as barbiturates and benzodiazepines, which allosterically enhance $\mathrm{GABA}_{\mathrm{A}}$ receptor function (Macdonald and Olsen, 1994). There is also considerable evidence in support of the hypothesis that the behavioral and cognitive effects of ethanol are mediated, at least in part, via a potentiation of $\mathrm{GABA}_{\mathrm{A}}$ receptor-mediated synaptic inhibition (Grobin et al., 1998; Mihic, 1999). Despite the popularity of this hypothesis, considerable controversy remains. For example, studies that have examined the direct effects of ethanol on GABAergic synaptic transmission have reported potentiation (Proctor et al., 1992b; Weiner et al., 1994, 1997; Poelchen et al., 2000; Roberto et al., 2003), inhibition (Siggins et al., 1987), or no effect (Siggins et al., 1987; Soldo et al., 1994), and the reasons for these disparate results remain poorly understood. Interestingly, several studies have noted that blockade of $\mathrm{GABA}_{\mathrm{B}}$ receptors can dramatically enhance the acute potentiating effect of ethanol on $\mathrm{GABA}_{\mathrm{A}}$ receptor-mediated IPSCs in the rat hippocampus (Wan et al., 1996; Kang et al., 1998). These studies suggest that some unknown $\mathrm{GABA}_{\mathrm{B}}$ receptor-dependent process may play an important role in regulating the ethanol sensitivity of GABAergic synapses. Most GABAergic synapses contain both presynaptic and postsynaptic $G_{A B A}$ receptors. Presynaptic $G_{A B A}$ receptors function as autoreceptors, and their activation inhibits $\mathrm{GABA}_{\mathrm{A}}$ IPSCs, whereas postsynaptic $\mathrm{GABA}_{\mathrm{B}}$ receptors are primarily coupled to the activation of a potassium conductance (Misgeld et al., 1995). In this study, we demonstrate that ethanol 
exerts a novel facilitatory effect on presynaptic $\mathrm{GABA}_{\mathrm{B}}$ receptor function at GABAergic synapses in the rat CA1 region and that this interaction serves to actively limit the overall potentiating effect of ethanol at these synapses.

\section{Materials and Methods}

Slice preparation. Transverse hippocampal slices $(400 \mu \mathrm{m})$ were prepared from 4- to 6-week-old male Sprague Dawley rats. Slices were maintained at ambient temperature for at least $2 \mathrm{hr}$ in oxygenated artificial CSF (aCSF) containing (in $\mathrm{mm}$ ): $124 \mathrm{NaCl}, 3.3 \mathrm{KCl}, 2.4$ $\mathrm{MgCl}_{2}, 2.5 \mathrm{CaCl}_{2}, 1.2 \mathrm{KH}_{2} \mathrm{PO}_{4}, 10$ D-glucose, and $25 \mathrm{NaHCO}_{3}$, saturated with $95 \% \mathrm{O}_{2}$ and $5 \% \mathrm{CO}_{2}$.

Electrophysiological recordings. Slices were transferred to a recording chamber maintained at ambient temperature and superfused with aerated aCSF at $2 \mathrm{ml} / \mathrm{min}$. Recording electrodes were prepared from filamented borosilicate glass capillary tubes (inner diameter, $0.86 \mathrm{~mm}$ ) using a horizontal micropipette puller (P-97; Sutter Instruments, Novato, CA). Patch-clamp recordings were made using a filling solution containing $130 \mathrm{~mm}$ K-gluconate, $10 \mathrm{~mm} \mathrm{KCl,} 1$ mм EGTA, $100 \mu \mathrm{M} \mathrm{CaCl}_{2}$, 2 mм Mg-ATP, 200 $\mu \mathrm{M}$ Tris-guanosine $5^{\prime}$-triphosphate, and $10 \mathrm{~mm}$ HEPES, pH adjusted with $\mathrm{KOH}, 275-280 \mathrm{mOsm}$. In most experiments, $5 \mathrm{~mm} \mathrm{~N}-(2,6-$ dimethyl-phenylcarbamoylmethyl)-triethylammonium bromide (QX314) was included in the recording solution to block voltage-gated sodium currents and $\mathrm{GABA}_{\mathrm{B}}$ IPSCs in the CA1 neurons being recorded (Horn et al., 1980; Nathan et al., 1990). QX-314 was omitted from the filling solution in experiments measuring postsynaptic $\mathrm{GABA}_{\mathrm{B}}$ receptor function (see Fig. 3). Whole-cell patch-clamp recordings were made from CA1 pyramidal neurons voltage-clamped at -45 to $-60 \mathrm{mV}$. Only cells with a stable access resistance of 5-20 $\mathrm{M} \Omega$ were used in these experiments. Whole-cell currents were acquired using an Axoclamp 2B or Axopatch 200B amplifier, digitized (Digidata1200 or Digidata 1321A; Axon Instruments, Union City, CA), and analyzed on- and off-line using an IBM-compatible personal computer and pClamp 8.0 or 9.0 software (Axon Instruments). In one set of experiments, we recorded spontaneous $\mathrm{GABA}_{\mathrm{A}}$ IPSCs (sIPSCs) using a filling solution identical to that described above, except that $140 \mathrm{~mm} \mathrm{CsCl}_{2}$ was substituted for K-gluconate and $\mathrm{KCl}$. sIPSCs were digitized at $5-10 \mathrm{kHz}$ in continuous 3 min epochs. Spontaneous events in each epoch were first identified using Clampfit event detection software (pClamp 9.0), and then all events were visually inspected to avoid inclusion of spurious responses in the data analysis $(<2 \%$ of detected events were rejected). sIPSCs in each epoch were then averaged, and the amplitude and area of averaged traces were calculated using the Statistics function included in the Clampfit program (pClamp 9.0).

Pharmacological isolation of synaptic currents. GABA $\mathrm{A}$ IPSCs were evoked every $20 \mathrm{sec}$ by electrical stimulation ( $0.2 \mathrm{msec}$ duration) using a concentric bipolar stimulating electrode (FHC, Bowdoinham, ME) placed near the CA1 somatic layer ["proximal" stimulation (Weiner et al., 1997)]. Stimulation intensity was adjusted to evoke responses that were $10-20 \%$ of maximal currents (typically $50-200 \mathrm{pA}$ ). GABA IPSCs $_{\mathrm{A}}$ were pharmacologically isolated using a mixture of $50 \mu \mathrm{M}$ APV and 20 $\mu \mathrm{M}$ DNQX to block NMDA and AMPA/kainate receptors, respectively. $\mathrm{GABA}_{\mathrm{B}}$ IPSCs were recorded in the presence of a similar mixture that also included $20 \mu \mathrm{m}$ bicuculline methiode to block $\mathrm{GABA}_{\mathrm{A}}$ receptors. Unless otherwise stated, all drugs used were purchased from Sigma (St. Louis, MO). Drugs were made up as 100 - to 400 -fold concentrates and applied to slices via calibrated syringe pumps (Razel Scientific Instruments, Stamford, CT). A $4 \mathrm{~m}$ ethanol solution was prepared immediately before each experiment from a 95\% stock solution (Aaper Alcohol and Chemical, Shelbyville, KY) kept in a glass storage bottle.

Statistics. Drug effects were quantified as the percentage change in the area under the curve of synaptic currents relative to the mean of control and washout values. Statistical analyses of drug effects were performed using the two-tailed Student's paired or unpaired $t$ tests or a one-way ANOVA followed by the Newman-Keuls post hoc test with a minimal level of significance of $p<0.05$.

\section{Results}

$\mathrm{A} \mathrm{GABA}_{\mathrm{B}}$ receptor antagonist enhances ethanol potentiation of proximal GABA IPSCs $_{A}$

Several studies have shown that $\mathrm{GABA}_{\mathrm{A}}$ IPSCs evoked by stimulation of perisomatic GABAergic synapses proximal to the CA1 pyramidal layer are reliably potentiated by pharmacologically relevant concentrations of ethanol, even in the absence of a $\mathrm{GABA}_{\mathrm{B}}$ receptor antagonist (Weiner et al., 1997; Poelchen et al., 2000; Proctor et al., 2003). Therefore, we first sought to determine whether a $\mathrm{GABA}_{\mathrm{B}}$ receptor antagonist enhanced ethanol potentiation of proximal hippocampal GABA $\mathrm{A}_{\mathrm{A}}$ IPSCs, as had been shown for ethanol potentiation of IPSCs evoked by stimulation of the stratum radiatum in this brain region (Wan et al., 1996). Under our standard recording conditions, bath application of 80 $\mathrm{mM}$ ethanol significantly potentiated the area of proximal GABA $_{\mathrm{A}}$ IPSCs $(72.8 \pm 7.8 \% ; n=14 ; p<0.01)$ (Fig. 1). This enhancement was stable for the duration of the ethanol application and reversed on ethanol washout. Pretreating slices with the $\mathrm{GABA}_{\mathrm{B}}$ receptor antagonist SCH $50911((+)-5,5$-dimethyl-2morpholineacetic acid hydrochloride) had no effect on $\mathrm{GABA}_{\mathrm{A}}$ IPSCs $(2.4 \pm 5.9 \%$ potentiation; $n=14 ; p>0.05)$. However, in the presence of SCH 50911, ethanol potentiation of proximal GABA $_{\mathrm{A}}$ IPSCs was significantly enhanced (121.5 $\pm 12.7 \% ; n=$ $14 ; p<0.05$ ) (Fig. 1). Because of the long duration required for these and many of the experiments in this study, recordings were performed at ambient temperature, which we found to increase the stability of patch clamp recordings in brain slices. However, we did examine the effect of SCH 50911 on ethanol potentiation of $\mathrm{GABA}_{\mathrm{A}}$ IPSCs in nine slices maintained at $32^{\circ} \mathrm{C}$. In these slices, we observed no difference in the magnitude of the acute effect of 80 mM ethanol ( $62.5 \pm 19.0 \%$ potentiation; $n=9 ; p<0.05)$ or 20 $\mu \mathrm{M}$ SCH 50911 alone $(3.8 \pm 6.8 \%$ inhibition; $n=9 ; p>0.05)$ or the effect of ethanol in the presence of SCH 50911 (127.7 \pm 15.4 ; $n=9 ; p<0.05)$. 
A
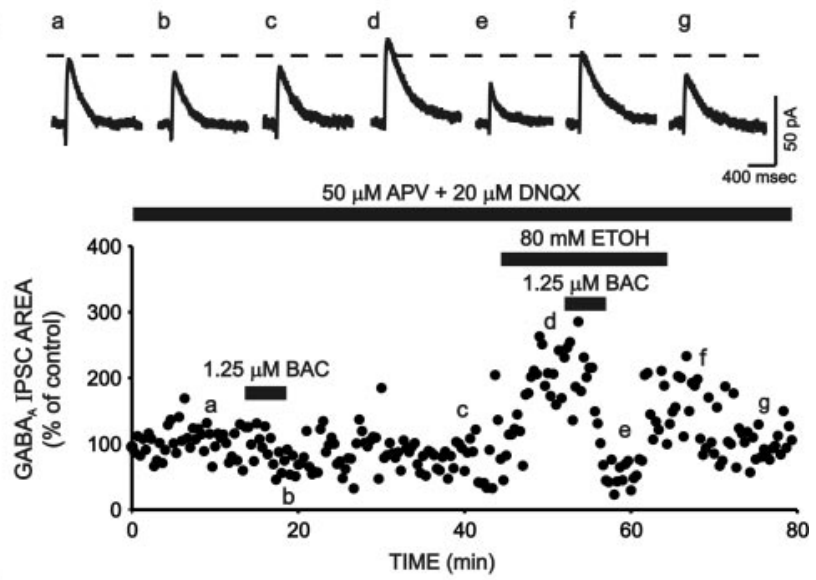

B

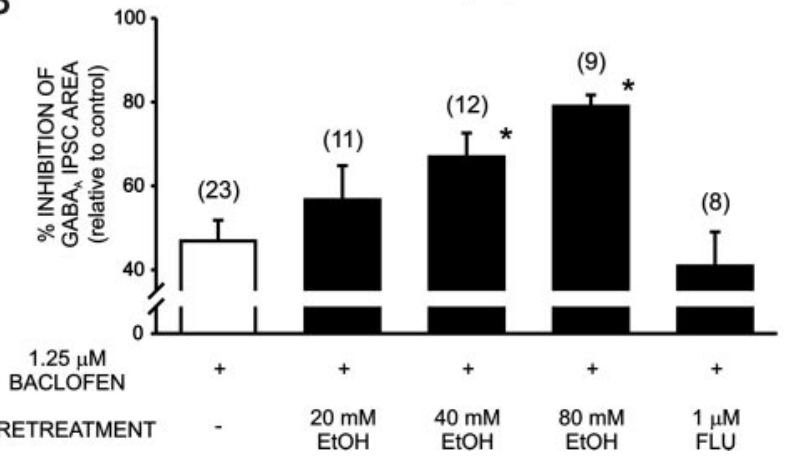

Figure 2. Ethanol increases presynaptic $G A B A_{B}$ receptor function. $A$, Representative time course illustrating the effect of $1.25 \mu \mathrm{m}$ baclofen (BAC) in the absence and presence of $80 \mathrm{~mm}$ ethanol (EtOH) on the area of proximal $\mathrm{GABA}_{A}$ IPSCS. Responses were pharmacologically isolated as in Figure 1. Traces above the graph are averages of six to eight IPSCs evoked at the times indicated by the corresponding letters. $B$, Bar graph summarizing the effect of $1.25 \mu \mathrm{M} B A C$ on proximal GABA $A_{A}$ IPSCS when applied alone or in the presence of 20,40, or $80 \mathrm{~mm}$ EtOH or $1 \mu \mathrm{M}$ FLU. ${ }^{*} p<0.05$, relative to $B A C$ alone, post hoc Neuman-Keuls test. Numbers in parentheses represent the number of cells tested under each experimental condition.

\section{Ethanol increases presynaptic $\mathrm{GABA}_{\mathrm{B}}$ receptor activity}

The preceding experiments suggest that some unknown $\mathrm{GABA}_{\mathrm{B}}$ receptor-mediated process may actively limit ethanol potentiation of proximal $\mathrm{GABA}_{\mathrm{A}}$ IPSCs in the rat hippocampal CA1 region. Activation of presynaptic $\mathrm{GABA}_{B}$ receptors at these and many other inhibitory synapses in the mammalian CNS produces a well characterized inhibition of GABA release along with an associated decrease in the size of evoked GABA ${ }_{\mathrm{A}}$ IPSCs (Bowery and Enna, 2000; Couve et al., 2000). We hypothesized that ethanol may enhance the activity of these presynaptic $\mathrm{GABA}_{\mathrm{B}}$ autoreceptors and that such an interaction could serve to reduce the overall potentiating effect of ethanol at these synapses. To test this hypothesis, we assayed the effect of ethanol on presynaptic $\mathrm{GABA}_{\mathrm{B}}$ receptor function at proximal GABAergic synapses. We determined the effect of a submaximal concentration of the $\mathrm{GABA}_{\mathrm{B}}$ receptor agonist baclofen on the area of proximal $\mathrm{GABA}_{\mathrm{A}}$ IPSCs in the absence and presence of $80 \mathrm{~mm}$ ethanol. These recordings were performed with $5 \mathrm{~mm}$ QX-314 in the patch pipette to block postsynaptic $\mathrm{GABA}_{\mathrm{B}}$ IPSCs (Nathan et al., 1990). Under these recording conditions, bath application of $1.25 \mu \mathrm{M}$ baclofen reduced the area of $\mathrm{GABA}_{\mathrm{A}}$ IPSCs by $46.9 \pm 5.0 \%(n=23)$ (Fig. 2). Pretreating slices with $80 \mathrm{~mm}$ ethanol resulted in a significant

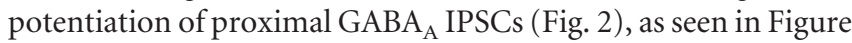
1 and previous studies (Weiner et al., 1997; Poelchen et al., 2000). However, once a new baseline was established in the presence of $80 \mathrm{~mm}$ ethanol, $1.25 \mu \mathrm{M}$ baclofen had a significantly greater in- hibitory effect on GABA $\mathrm{A}_{\mathrm{A}}$ IPSCs, reducing their area by an average of $79.0 \pm 2.7 \%(n=9)$ (Fig. 2). In five cells in which ethanol was washed out for at least $20 \mathrm{~min}$, baclofen inhibition of $\mathrm{GABA}_{\mathrm{A}}$ IPSCs returned to baseline levels ( $37.4 \pm 9.5 \%$ inhibition).

We next examined the effect of a range of ethanol concentrations on baclofen inhibition of $\mathrm{GABA}_{\mathrm{A}}$ IPSCs. Ethanol significantly enhanced the inhibitory effect of baclofen at 40 and 80 but not $20 \mathrm{~mm}$ (Fig. $2 \mathrm{~B}$ ), and the potency of this interaction was identical to that of the overall potentiating effect of ethanol at these synapses.

One possible confound of the above experiment is that, because ethanol potentiates proximal GABA $\mathrm{A}_{\mathrm{A}}$ IPSCs, it is possible that baclofen inhibition of proximal IPSCs is dependent on the initial size of these responses. To address this concern, we tested the effect of flunitrazepam (FLU), a well characterized benzodiazepine that potentiates $\mathrm{GABA}_{\mathrm{A}}$ receptor activity (Sieghart, $1995)$, on presynaptic $G_{A B A_{B}}$ receptor function. Bath application of $1 \mu \mathrm{M}$ FLU increased the proximal GABA $\mathrm{A}_{\mathrm{A}}$ IPSC area by $80.1 \pm 13.5 \%(n=8 ; p<0.01)$. After a new baseline was established, we tested the effect of $1.25 \mu \mathrm{M}$ baclofen on proximal IPSCs. Unlike ethanol, FLU pretreatment had no significant effect on baclofen inhibition of GABA ${ }_{\mathrm{A}}$ IPSCs (Fig. $2 B$ ).

\section{Ethanol has no effect on postsynaptic $\mathrm{GABA}_{\mathrm{B}}$ receptor function}

The preceding experiments provide evidence that ethanol potentiates presynaptic $\mathrm{GABA}_{\mathrm{B}}$ receptor function at proximal synapses in the rat hippocampus. Although this specific interaction has not been previously examined, several studies have characterized the acute effects of ethanol on postsynaptic $\mathrm{GABA}_{\mathrm{B}}$ receptor activity in the hippocampus and have reported no effect of ethanol at concentrations similar to those used in our studies (Frye et al., 1991; Frye and Fincher, 1996; Wan et al., 1996). We performed two separate experiments to evaluate possible effects of ethanol on postsynaptic $\mathrm{GABA}_{\mathrm{B}}$ receptor function under our recording conditions. First, we tested the effect of ethanol on $\mathrm{GABA}_{\mathrm{B}}$ IPSCs recorded from rat hippocampal CA1 pyramidal neurons. $\mathrm{GABA}_{\mathrm{B}}$ IPSCs were evoked by electrical stimulation of the stratum lacunosum in the presence of $50 \mu \mathrm{M}$ APV and $20 \mu \mathrm{M}$ DNQX, to block glutamatergic synaptic responses, and $20 \mu \mathrm{M}$ bicuculline methio-

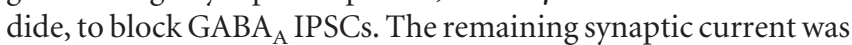
completely blocked by $20 \mu \mathrm{M} \mathrm{SCH} \mathrm{50911,} \mathrm{indicating} \mathrm{that} \mathrm{it} \mathrm{was}$ mediated by the activation of $\mathrm{GABA}_{\mathrm{B}}$ receptors (Fig. $3 A$ ). Under these recording conditions, $80 \mathrm{~mm}$ ethanol had no effect on the area of $\mathrm{GABA}_{\mathrm{B}}$ IPSCs $(4.3 \pm 8.3 \%$ potentiation; $n=7 ; p>0.05$ ) (Fig. 3A).

In the second experiment, we tested the effect of ethanol on outward currents elicited by bath application of the $\mathrm{GABA}_{\mathrm{B}}$ receptor agonist baclofen in cells voltage-clamped at $-50 \mathrm{mV}$. This protocol has been used in other studies to activate the G-protein coupled inwardly rectifying potassium channels that underlie the slow $\mathrm{GABA}_{\mathrm{B}}$ IPSCs recorded in Figure $3 A$ (Newberry and Nicoll, 1984; Gahwiler and Brown, 1985; Sodickson and Bean, 1996; Liu and Leung, 2003). Under our recording conditions, bath application of $20 \mu \mathrm{M}$ baclofen induced an outward current of $76.1 \pm$ $14.8 \mathrm{pA}(n=5)$ (Fig $3 B)$. Ethanol pretreatment $(80 \mathrm{~mm})$ had no effect on currents evoked by $20 \mu \mathrm{M}$ baclofen $(68.9 \pm 8.6 \mathrm{pA} ; n=$ $5 ; p>0.05)$. Although ethanol alone appeared to induce a small outward current in the example illustrated, this effect was not significant and has not been consistently observed in other studies (Frye and Fincher, 1996; Wan et al., 1996). 
A

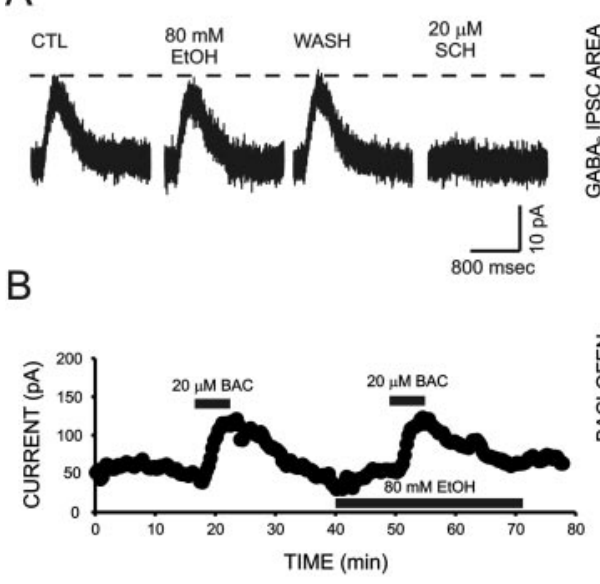

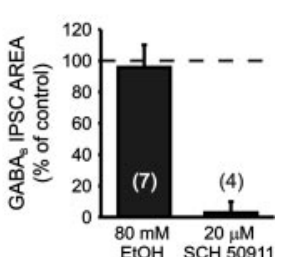

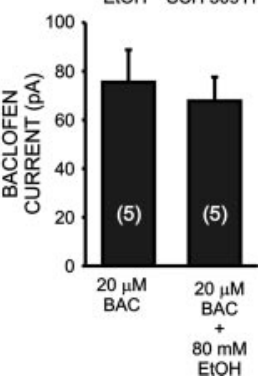

A

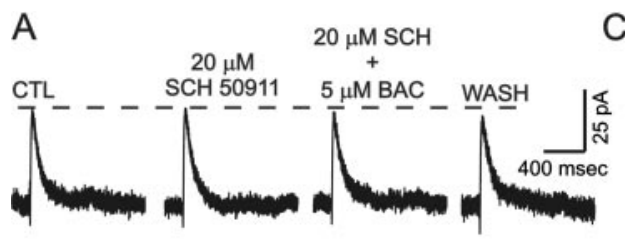

B

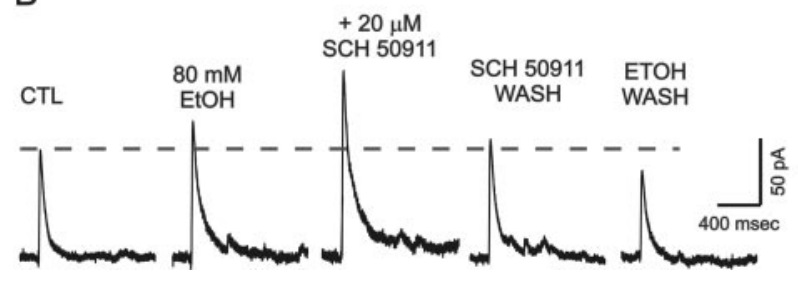

Figure 3. Ethanol does not potentiate postsynaptic $\mathrm{GABA}_{B}$ receptor function in rat $\mathrm{CA1}$ pyramidal neurons. $A$, Representative traces illustrating the effect of $80 \mathrm{~mm}$ ethanol (EtOH) and 20 $\mu \mathrm{M} S \mathrm{SH} 50911$ on the area of GABA $\mathrm{BPSCS}$ evoked by stimulation of the stratum lacunosummoleculare in the presence of APV, DNQX, and $20 \mu \mathrm{m}$ bicuculline methiodide. Traces are averages of five $G_{A B A}$ IPSCS recorded under the conditions indicated. The bar graph summarizes the effect of $\mathrm{EtOH}$ and $\mathrm{SCH} 50911$ on the area of $\mathrm{AABA}_{B}$ IPSCS. CTL, Control; WASH, washout. $B$, Representative time course of the outward current generated by bath application of $20 \mu \mathrm{m}$ baclofen (BAC) in the absence and presence of $80 \mathrm{~mm} \mathrm{EtOH}$. The bar graph summarizes the maximal amplitude of BAC-evoked currents recorded in the absence and presence of $\mathrm{EtOH}$. Numbers in parentheses represent the number of cells tested under each experimental condition.

\section{Ethanol enhances presynaptic $\mathrm{GABA}_{\mathrm{B}}$ receptor tone}

The results of these studies suggest that ethanol selectively enhances presynaptic but not postsynaptic $\mathrm{GABA}_{\mathrm{B}}$ receptor activity at GABAergic synapses in the rat hippocampal CA1 region. Because this interaction occurs across the same ethanol concentration range that results in an overall potentiation of proximal $\mathrm{GABA}_{\mathrm{A}}$ IPSCs, this presynaptic interaction likely serves to reduce the overall potentiating effect of ethanol at these synapses. This interaction may thus account for the observation that a $G_{A B A}$ receptor antagonist can facilitate ethanol potentiation of $\mathrm{GABA}_{\mathrm{A}}$ IPSCs in this brain region. However, this interpretation implies that there must be some tonic presynaptic $\mathrm{GABA}_{\mathrm{B}}$ receptor activity in the presence of ethanol. To address this issue, we examined the effect of the $\mathrm{GABA}_{\mathrm{B}}$ receptor antagonist SCH 50911 on the area of proximal $\mathrm{GABA}_{\mathrm{A}}$ IPSCs in the absence and presence of 80 $\mathrm{mm}$ ethanol. As shown in Figure 1, bath application of $20 \mu \mathrm{M} \mathrm{SCH}$

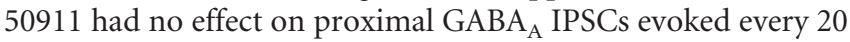
$\sec (4.0 \pm 8.0 \%$ inhibition; $n=9 ; p>0.05)$. This concentration of SCH 50911 was, however, sufficient to completely block the inhibitory effect of baclofen on these responses (compare Figs. $2 A, 4 A$ ). Notably, in the presence of $80 \mathrm{~mm}$ ethanol, SCH 50911 significantly potentiated proximal $\mathrm{GABA}_{\mathrm{A}}$ IPSCs $(35.9 \pm 4.1 \%$ potentiation; $n=11 ; p<0.05$ ) (Fig. 4). The results of this experiment demonstrate that, in the presence but not the absence of ethanol, presynaptic $\mathrm{GABA}_{\mathrm{B}}$ receptor activity tonically inhibits proximal GABAergic synapses in the rat hippocampal CA1 region.

Pretreatment with a $\mathrm{GABA}_{\mathrm{B}}$ receptor antagonist selectively enhances ethanol potentiation of sIPSC frequency

We performed one additional series of experiments to further address both the mechanism through which ethanol enhances $\mathrm{GABA}_{\mathrm{A}}$ receptor-mediated synaptic transmission in the CA1 re-

Figure 4. Ethanol increases presynaptic $G_{A B A_{B}}$ receptor tone. Traces from representative experiments illustrate that $20 \mu \mathrm{m} \mathrm{SCH} 50911$ potentiates the area of proximal GABA $\mathrm{IPSC}_{\mathrm{A}}$ in the presence $(B)$ but not the absence $(A)$ of ethanol $(\mathrm{EtOH})$. Note that this concentration of $\mathrm{SCH}$ 50911 is sufficient to completely block the inhibitory effect of $5 \mu \mathrm{m} B A C$ on GABA $A_{A}$ IPSCS. CTL, Control; WASH, washout. C, Summary of the effect of $20 \mu \mathrm{M} \mathrm{SCH} 50911$ on the area of $\mathrm{GABA}_{A}$ IPSCs recorded in the absence and presence of $\mathrm{Et} O \mathrm{H}$. ${ }^{*} p<0.05$, relative to control. Numbers in parentheses represent the number of cells tested under each experimental condition.

gion and the facilitation of this effect by blockade of $\mathrm{GABA}_{\mathrm{B}}$ receptors. In these experiments, CA1 pyramidal neurons were voltage-clamped at $-70 \mathrm{mV}$, and $\mathrm{GABA}_{\mathrm{A}}$ sIPSCs were recorded in the presence of the glutamate receptor antagonist mixture used in the evoked $\mathrm{GABA}_{\mathrm{A}}$ IPSC experiments. Under these recording conditions, the majority of neurons exhibited spontaneous synaptic responses that reversed near $0 \mathrm{mV}$ and were completely blocked by the $\mathrm{GABA}_{\mathrm{A}}$ receptor antagonist bicuculline methiodide $(20 \mu \mathrm{M})$ (data not shown). In the first experiment, we tested the effect of $80 \mathrm{~mm}$ ethanol alone on the frequency, amplitude, and area of sIPSCs. Bath application of ethanol significantly and reversibly increased all three parameters (Fig. 5A,C) (frequency, $39.2 \pm 6.6 \%$ potentiation; $p<0.001$; amplitude, $16.7 \pm 5.6 \%$ potentiation; $p<0.05$; area, $21.9 \pm 6.7 \%$ potentiation; $p<0.05$; $n=10$ ), with the increase in sIPSC frequency appearing to be the most robust effect (Fig. 5C). In the second experiment, we tested the effect of the $\mathrm{GABA}_{\mathrm{B}}$ receptor antagonist SCH $50911(20 \mu \mathrm{M})$ and SCH 50911 plus $80 \mathrm{~mm}$ ethanol on sIPSCs. Pretreating slices with SCH 50911 alone had no effect on any of the SIPSC parameters measured (frequency, $1.4 \pm 8.2 \%$ potentiation; $p>0.05$; amplitude, $2.1 \pm 5.2 \%$ potentiation; $p>0.05$; area, $1.0 \pm 4.9 \%$ inhibition; $p>0.05 ; n=11$ ) (Fig. $5 B, C$ ). However, in the presence of SCH 50911, ethanol enhancement of sIPSC frequency was significantly greater than that observed when ethanol was applied alone $(99.8 \pm 8.6 \%$ potentiation; $p<0.001)$ (Fig. $5 B, C)$. In contrast, ethanol potentiation of sIPSC amplitude and area were not significantly altered by pretreatment with the $\mathrm{GABA}_{\mathrm{B}}$ receptor antagonist (amplitude, $18.7 \pm 7.3 \%$ potentiation; area, $30.6 \pm$ 8.5 potentiation; $n=11$ ) (Fig. $5 B, C$ ).

\section{A subthreshold concentration of baclofen selectively blocks} ethanol potentiation of proximal $\mathrm{GABA}_{\mathrm{A}}$ IPSCs

Because ethanol appears to enhance tonic presynaptic $\mathrm{GABA}_{\mathrm{B}}$ receptor activity, it might be possible to antagonize ethanol potentiation of proximal $\mathrm{GABA}_{\mathrm{A}}$ IPSCs by pretreating slices with a low, subthreshold concentration of a $\mathrm{GABA}_{\mathrm{B}}$ receptor agonist. To test this hypothesis, we examined the effect of $80 \mathrm{~mm}$ ethanol on proximal $\mathrm{GABA}_{\mathrm{A}}$ IPSCs in the absence and presence of a 
A

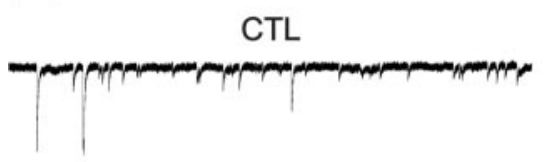

$80 \mathrm{mM}$ EtOH

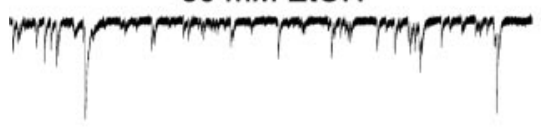

WASH

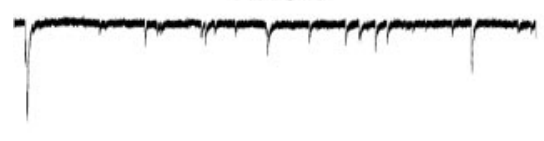

B

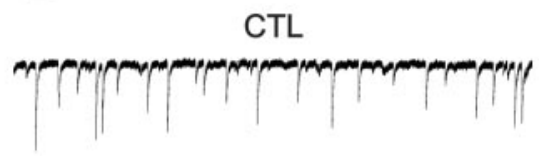

$20 \mu \mathrm{M}$ SCH 50911

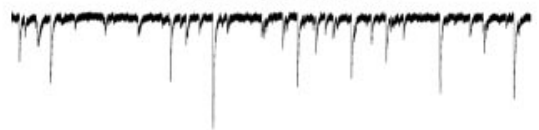

$+80 \mathrm{mM}$ EtOH

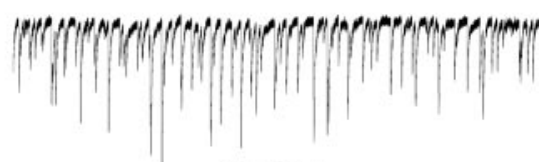

WASH

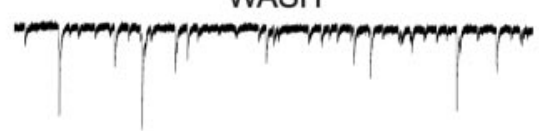

SCs. In contrast to the inhibitory effect of baclofen pretreatment on ethanol potentiation of proximal IPSCs, baclofen had no effect on flunitrazepam or pentobarbital potentiation of these responses. Bath application of $1 \mu \mathrm{M}$ flunitrazepam potentiated $\mathrm{GABA}_{\mathrm{A}}$ IPSCs to $198.0 \pm 19.2 \%$ under control conditions $(n=8)$ and to $209.7 \pm 19.2 \%$ of control in the presence of $500 \mathrm{~nm}$ baclofen $(n=5)$. Similar results were observed with $50 \mu \mathrm{M}$ pentobarbital ( $254 \pm 31.3 \%$ of control in the absence of baclofen; $n=5 ; 228.1 \pm 27.8 \%$ of control in the presence of baclofen; $n=5$ ) (Fig. 7).

\section{Discussion}

The results of this study suggest that acute ethanol exposure enhances presynaptic $\mathrm{GABA}_{\mathrm{B}}$ receptor function at proximal GABAergic synapses in the rat CA1 region. This interaction occurs across the same concentration range over which ethanol potentiates $\mathrm{GABA}_{\mathrm{A}}$ IPSCs at these synapses. Because presynaptic $\mathrm{GABA}_{\mathrm{B}}$ receptor activity reduces evoked GABA release (Misgeld et al., 1995), this interaction appears to actively limit the overall potentiating effect of ethanol at these synapses.

Although there is now compelling behavioral evidence that ethanol acts, in part, by potentiating $\mathrm{GABA}_{\mathrm{A}}$ receptor function (Grobin et al., 1998), direct evidence that ethanol actually enhances $\mathrm{GABA}_{\mathrm{A}}$ receptor-mediated synaptic inhibition has been somewhat difficult to demonstrate, particularly in the hippocampus. Our results suggest that variability in the level of presynaptic $\mathrm{GABA}_{\mathrm{B}}$ receptor activity, attributable to differences in the stimulation protocols used to evoke IPSCs, may have contributed to much of the disparity in the reported effects of ethanol on hippocampal GABAergic synapses. For example, within the CA1 region, ethanol has been reported to have little or no effect on compound IPSCs mediated by both $\mathrm{GABA}_{\mathrm{A}}$ and $\mathrm{GABA}_{\mathrm{B}}$ receptors (Siggins et al., 1987; Proctor et al.,

subthreshold concentration of baclofen. Under our recording conditions, a concentration of $500 \mathrm{~nm}$ baclofen was determined to be just below the threshold to elicit a significant inhibition of

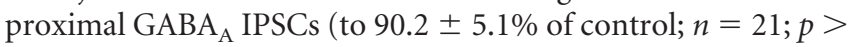
$0.05)$. We therefore pretreated slices with $500 \mathrm{nM}$ baclofen and tested the effect of $80 \mathrm{~mm}$ ethanol on proximal IPSCs (Figs. 6, 7). Although $80 \mathrm{~mm}$ ethanol produced a robust potentiation of prox-

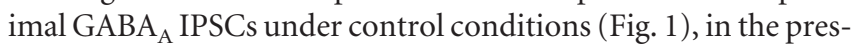
ence of $500 \mathrm{~nm}$ baclofen, $80 \mathrm{~mm}$ ethanol caused a modest but

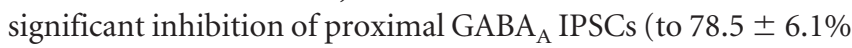
of control; $p<0.05 ; n=11$ ). In a few cells, we were able to wash out the baclofen for at least $30 \mathrm{~min}$ and challenge slices again with the same concentration of ethanol. After baclofen washout, 80

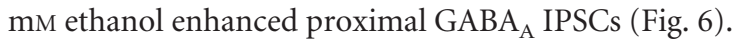

We next examined the effect of $500 \mathrm{~nm}$ baclofen pretreatment on flunitrazepam and pentobarbital potentiation of $\mathrm{GABA}_{\mathrm{A}} \mathrm{IP}$ - 1992a; Wan et al., 1996). Synaptic activation of $\mathrm{GABA}_{\mathrm{B}}$ receptors typically requires relatively intense stimulation or trains of stimuli (Thomson and Destexhe, 1999; Liu and Leung, 2003), possibly reflecting an extrasynaptic localization of these receptors

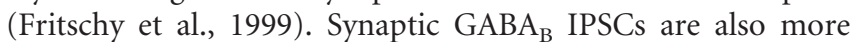
readily evoked by stimulation of dendritic fields of the CA1 region (Williams and Lacaille, 1992; Thompson, 1994). In contrast, data presented in this study, as well as those of several other reports (Weiner et al., 1997; Poelchen et al., 2000; Crowder et al., 2002; Proctor et al., 2003), demonstrate that GABA APSCs $_{\text {A }}$ evoked by minimal stimulation of perisomatic synapses in the CA1 region are reliably potentiated by intoxicating concentrations of ethanol. Our data suggest that the ethanol insensitivity of compound GABAergic synaptic responses may reflect a greater degree of presynaptic $\mathrm{GABA}_{\mathrm{B}}$ receptor modulation of such re- 
sponses. In fact, presynaptic $\mathrm{GABA}_{\mathrm{B}}$ receptor activity inhibits dendritic IPSCs to a greater extent than those evoked by perisomatic stimulation (Lambert and Wilson, 1993b; Pearce et al., 1995). This hypothesis is further supported by the observation that blockade of $\mathrm{GABA}_{\mathrm{B}}$ receptors converts ethanol-insensitive compound IPSCs into ones that are reliably potentiated by ethanol (Wan et al., 1996) and by data presented in this study that a minimal elevation of presynaptic $\mathrm{GABA}_{\mathrm{B}}$ receptor tone, by pretreating slices with a subthreshold concentration of baclofen, was sufficient to convert ethanol-sensitive proximal $\mathrm{GABA}_{\mathrm{A}}$ IPSCs into responses that were actually inhibited by ethanol. Taken together, these data are consistent with the hypothesis that variation in the degree of presynaptic $\mathrm{GABA}_{\mathrm{B}}$ receptor activity can profoundly influence ethanol modulation of $\mathrm{GABA}_{\mathrm{A}}$ IPSCs in the hippocampus and that such variability may have contributed significantly to the disparity noted in earlier studies on ethanol modulation of GABAergic neurotransmission in this brain region.

It should be noted that, although proximal $\mathrm{GABA}_{\mathrm{A}}$ IPSCs were potentiated by ethanol under our standard recording conditions (i.e., in the absence of a $\mathrm{GABA}_{\mathrm{B}}$ receptor antagonist), pretreatment with a $\mathrm{GABA}_{\mathrm{B}}$ receptor antagonist significantly increased the ethanol sensitivity of these responses. Therefore, presynaptic $\mathrm{GABA}_{\mathrm{B}}$ receptor function can regulate the ethanol sensitivity of GABAergic synapses that are not under tonic regulation by these receptors. Interestingly, recent reports have demonstrated a strong correlation between the in vitro ethanol sensitivity of proximal $\mathrm{GABA}_{\mathrm{A}}$ IPSCs and behavioral sensitivity to some of the intoxicating effects of ethanol. This relationship has been found in lines of rats and mice bred for differences in ethanol-induced loss of the righting reflex (Poelchen et al., 2000) as well as in PKC $\gamma$ or $\epsilon$ knock-out mice, which also exhibit alterations in a variety of ethanol-mediated behavioral effects (Harris et al., 1995; Hodge et al., 1999). In all of these rodent lines, proximal IPSCs from ethanol-sensitive strains were potentiated to a greater extent by ethanol than IPSCs recorded from slices prepared from the ethanol-resistant lines (Poelchen et al., 2000; Proctor et al., 2003). These findings suggest that factors that regulate the ethanol sensitivity of proximal $\mathrm{GABA}_{\mathrm{A}}$ IPSCs may also influence behavioral responsiveness to ethanol. Given that presynaptic $\mathrm{GABA}_{\mathrm{B}}$ receptor activity can profoundly influence the ethanol sensitivity of these synapses, it will be important in future studies to determine whether functional differences in presynaptic $\mathrm{GABA}_{\mathrm{B}}$ receptor activity contribute to these previously described in vitro and in vivo differences in ethanol sensitivity in these selected lines.

The importance of elucidating the physiological factor(s) that can influence behavioral sensitivity to ethanol is further under- scored by epidemiological studies suggesting that lower initial sensitivity to ethanol may be an important risk factor associated with an elevated risk of developing ethanol-related problems later in life (Schuckit, 1994; Schuckit and Smith, 1996). Although much effort has been directed at identifying genetic differences that may contribute to the variance in behavioral responsiveness to ethanol consumption, the specific genes responsible for such differences remain mostly unknown. Our findings suggest that genes encoding for $\mathrm{GABA}_{\mathrm{B}}$ receptors, or any proteins that may modulate the activity of the cascade linking presynaptic $\mathrm{GABA}_{\mathrm{B}}$ receptor activation to a reduction in $\mathrm{GABA}$ release, represent genetic loci that could potentially be associated with an increased risk of alcoholism.

Another important question that remains to be fully addressed is the mechanism through which ethanol enhances presynaptic $G_{A B A}$ receptor function. One possibility is that ethanol interacts directly with presynaptic $\mathrm{GABA}_{\mathrm{B}}$ receptors. Our finding that ethanol potentiates baclofen inhibition of proximal $\mathrm{GABA}_{\mathrm{A}}$ 
IPSCs is consistent with such a mechanism. However, our data and those of others (Frye and Fincher, 1996; Wan et al., 1996) also suggest that ethanol does not enhance postsynaptic $\mathrm{GABA}_{\mathrm{B}}$ receptor function in the $\mathrm{CA} 1$ region. All $\mathrm{GABA}_{\mathrm{B}}$ receptors are heterodimers comprising $\mathrm{GABA}_{\mathrm{B} 1}$ and $\mathrm{GABA}_{\mathrm{B} 2}$ subunits (Bowery and Enna, 2000; Enna, 2001), and genetic deletion of the $\mathrm{GABA}_{\mathrm{B} 1}$ isoform completely abolishes presynaptic and postsynaptic $\mathrm{GABA}_{\mathrm{B}}$ receptor function (Prosser et al., 2001). These findings suggest a single, pharmacologically homogeneous distribution of $\mathrm{GABA}_{\mathrm{B}}$ receptors in the CNS. It therefore seems unlikely that ethanol could directly interact with presynaptic $G_{A B A}$ receptors but be devoid of activity at their postsynaptic counterparts. It should, however, be noted that ethanol has been shown to potentiate postsynaptic $\mathrm{GABA}_{\mathrm{B}}$ receptor function in regions other than the hippocampus [e.g., cerebellar granule neurons (Lewohl et al., 1999)]. In addition, our data do not rule out the possibility that ethanol acts directly on some element of the downstream cascade linking presynaptic $\mathrm{GABA}_{\mathrm{B}}$ receptor activation to the inhibition of GABA release because distinct coupling mechanisms are thought to mediate presynaptic and postsynaptic $\mathrm{GABA}_{\mathrm{B}}$ receptor signaling in the hippocampus (Thompson and Gahwiler, 1992; Lambert and Wilson, 1993a; Pitler and Alger, 1994).

An alternative hypothesis that is consistent with much of our data is that ethanol may actually enhance GABAergic synaptic transmission, in part, via an increase in GABA release. Such an effect might raise ambient $G A B A$ levels to a level sufficient to enhance presynaptic $\mathrm{GABA}_{\mathrm{B}}$ receptor function. In fact, $\mathrm{GABA}_{\mathrm{B}}$ receptors have a much lower functional $\mathrm{EC}_{50}$ than do $\mathrm{GABA}_{\mathrm{A}}$ receptors (Sodickson and Bean, 1996), and extracellular GABA levels have been estimated to be very near the threshold that we observed for activation of presynaptic $\mathrm{GABA}_{\mathrm{B}}$ receptors at proximal GABAergic synapses $(\sim 0.5-1 \mu \mathrm{M})$ (Lerma et al., 1986; Tossman et al., 1986).

Direct evidence in support of this hypothesis stems from our finding that bath application of ethanol significantly increased the frequency of sIPSCs onto CA1 neurons. This finding is consistent with other recent studies demonstrating ethanol-mediated presynaptic enhancement of action potential-dependent(Carta et al., 2003) and -independent (Sanna et al., 2004) GABA release in the hippocampus and amygdala (Roberto et al., 2003; Nie et al., 2004) as well as action potential-dependent GABA release onto cerebellar granule cells (Carta et al., 2004). In addition, although ethanol significantly increased the amplitude and area of sIPSCs in this study, possibly reflecting postsynaptic actions of this drug, pretreatment with a $\mathrm{GABA}_{\mathrm{B}}$ receptor antagonist only facilitated the presynaptic ethanol enhancement of sIPSC frequency. An ethanol-mediated elevation of ambient GABA levels could also account for our observation that the $\mathrm{GABA}_{\mathrm{B}}$ receptor antagonist SCH 50911 potentiated GABA $_{A}$ IPSCs in the presence but not the absence of ethanol. This mechanism may also explain why the facilitatory effects of flunitrazepam and pentobarbital (allosteric potentiators of $\mathrm{GABA}_{\mathrm{A}}$ receptor activity that do not enhance GABA release) on proximal $\mathrm{GABA}_{\mathrm{A}}$ IPSCs are not subject to modulation by presynaptic $\mathrm{GABA}_{\mathrm{B}}$ receptor activity.

Additional studies are clearly needed to fully elucidate the complex mechanisms through which ethanol modulates GABAergic synaptic inhibition in the rat hippocampus and other brain regions. Nevertheless, our data clearly demonstrate that ethanol can enhance presynaptic $\mathrm{GABA}_{\mathrm{B}}$ receptor activity and that this interaction regulates the overall ethanol sensitivity of perisomatic hippocampal GABAergic synapses. These findings, coupled with the observation that ethanol can increase GABA release in the hippocampus and other brain regions, provide further evidence that ethanol modulation of GABAergic neurotrans- mission likely involves more than just a simple, allosteric interaction with the postsynaptic $\mathrm{GABA}_{\mathrm{A}}$ receptor complex.

\section{References}

Bowery NG, Enna SJ (2000) Gamma-aminobutyric acid(B) receptors: first of the functional metabotropic heterodimers. J Pharmacol Exp Ther 292:2-7.

Carta M, Ariwodola OJ, Weiner JL, Valenzuela CF (2003) Alcohol potently inhibits the kainate receptor-dependent excitatory drive of hippocampal interneurons. Proc Natl Acad Sci USA 100:6813-6818.

Carta M, Mameli M, Valenzuela CF (2004) Alcohol enhances GABAergic transmission to cerebellar granule cells via an increase in Golgi cell excitability. J Neurosci 24:3746-3751.

Couve A, Moss SJ, Pangalos MN (2000) GABA $_{B}$ receptors: a new paradigm in G protein signaling. Mol Cell Neurosci 16:296-312.

Crowder TL, Ariwodola OJ, Weiner JL (2002) Ethanol antagonizes kainate receptor-mediated inhibition of evoked GABA(A) inhibitory postsynaptic currents in the rat hippocampal CA1 region. J Pharmacol Exp Ther 303:937-944.

Deitrich RA, Dunwiddie TV, Harris RA, Erwin VG (1989) Mechanism of action of ethanol: initial central nervous system actions. Pharmacol Rev 41:489-537.

Enna SJ (2001) A GABA $A_{B}$ mystery: the search for pharmacologically distinct $\mathrm{GABA}_{\mathrm{B}}$ receptors. Mol Interv 1:208-218.

Faingold CL, N'Gouemo P, Riaz A (1998) Ethanol and neurotransmitter interactions-from molecular to integrative effects. Prog Neurobiol 55:509-535.

Fritschy JM, Meskenaite V, Weinmann O, Honer M, Benke D, Mohler H (1999) $\mathrm{GABA}_{\mathrm{B}}$-receptor splice variants GBla and GB1b in rat brain: developmental regulation, cellular distribution and extrasynaptic localization. Eur J Neurosci 11:761-768.

Frye GD, Fincher A (1996) Sensitivity of postsynaptic $\mathrm{GABA}_{\mathrm{B}}$ receptors on hippocampal CA1 and CA3 pyramidal neurons to ethanol. Brain Res 735:239-248.

Frye GD, Taylor L, Trzeciakowski JP, Griffith WH (1991) Effects of acute and chronic ethanol treatment on pre- and postsynaptic responses to baclofen in rat hippocampus. Brain Res 560:84-91.

Gahwiler BH, Brown DA (1985) GABAb-receptor-activated $\mathrm{K}^{+}$current in voltage-clamped CA3 pyramidal cells in hippocampal cultures. Proc Natl Acad Sci USA 82:1558-1562.

Grobin AC, Matthews DB, Devaud LL, Morrow AL (1998) The role of $\mathrm{GABA}(\mathrm{A})$ receptors in the acute and chronic effects of ethanol. Psychopharmacologia 139:2-19.

Harris RA, McQuilkin SJ, Paylor R, Abeliovich A, Tonegawa S, Wehner JM (1995) Mutant mice lacking the gamma isoform of protein kinase C show decreased behavioral actions of ethanol and altered function of gamma-aminobutyrate type A receptors. Proc Natl Acad Sci USA 92:3658-3662.

Hodge CW, Mehmert KK, Kelley SP, McMahon T, Haywood A, Olive MF, Wang D, Sanchez-Perez AM, Messing RO (1999) Supersensitivity to allosteric $\mathrm{GABA}(\mathrm{A})$ receptor modulators and alcohol in mice lacking PKCepsilon. Nat Neurosci 2:997-1002.

Horn R, Brodwick MS, Dickey WD (1980) Asymmetry of the acetylcholine channel revealed by quaternary anesthetics. Science 210:205-207.

Kang MH, Spigelman I, Olsen RW (1998) Alteration in the sensitivity of GABA(A) receptors to allosteric modulatory drugs in rat hippocampus after chronic intermittent ethanol treatment. Alcohol Clin Exp Res 22:2165-2173.

Kessler RC, McGonagle KA, Zhao S, Nelson CB, Hughes M, Eshleman S, Wittchen HU, Kendler KS (1994) Lifetime and 12-month prevalence of DSM-III-R psychiatric disorders in the United States: results from the National Comorbidity Survey. Arch Gen Psychiatry 51:8-19.

Krnjevic K (1991) Significance of GABA in brain function. In: GABA mechanisms in epilepsy (Tunnicliff G, Raess BU, eds), pp 47-87. New York: Wiley.

Lambert NA, Wilson WA (1993a) Discrimination of post- and presynaptic $\mathrm{GABA}_{\mathrm{B}}$ receptor-mediated responses by tetrahydroaminoacridine in area CA3 of the rat hippocampus. J Neurophysiol 69:630-635.

Lambert NA, Wilson WA (1993b) Heterogeneity in presynaptic regulation of GABA release from hippocampal inhibitory neurons. Neuron 11:1057-1067.

Lerma J, Herranz AS, Herreras O, Abraira V, Martin del Rio R (1986) In vivo 
determination of extracellular concentration of amino acids in the rat hippocampus: a method based on brain dialysis and computerized analysis. Brain Res 384:145-155.

Lewohl JM, Wilson WR, Mayfield RD, Brozowski SJ, Morrisett RA, Harris RA (1999) G-protein-coupled inwardly rectifying potassium channels are targets of alcohol action. Nat Neurosci 2:1084-1090.

Liu X, Leung LS (2003) Partial hippocampal kindling increases $G_{A B A}$ receptor-mediated postsynaptic currents in CA1 pyramidal cells. Epilepsy Res 57:33-47.

Macdonald RL, Olsen RW (1994) GABA $_{\mathrm{A}}$ receptor channels. Annu Rev Neurosci 17:569-602.

McGinnis JM, Foege WH (1999) Mortal and morbidity attributable to use of addictive substances in the United States. Proc Assoc Am Physicians 111:109-118.

Mihic SJ (1999) Acute effects of ethanol on $\mathrm{GABA}_{\mathrm{A}}$ and glycine receptor function. Neurochem Int 35:115-123.

Misgeld U, Bijak M, Jarolimek W (1995) A physiological role for $\mathrm{GABA}_{\mathrm{B}}$ receptors and the effects of baclofen in the mammalian central nervous system. Prog Neurobiol 46:423-462.

Nathan T, Jensen MS, Lambert JD (1990) The slow inhibitory postsynaptic potential in rat hippocampal CA1 neurones is blocked by intracellular injection of QX-314. Neurosci Lett 110:309-313.

Newberry NR, Nicoll RA (1984) Direct hyperpolarizing action of baclofen on hippocampal pyramidal neurons. Nature 308:450-452.

Nie Z, Schweitzer P, Roberts AJ, Madamba SG, Moore SD, Siggins GR (2004) Ethanol augments GABAergic transmission in the central amygdala via CRF1 receptors. Science 303:1512-1514.

Pearce RA, Grunder SD, Faucher LD (1995) Different mechanisms for use-

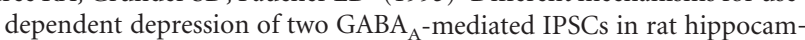
pus. J Physiol (Lond) 484:425-435.

Pitler TA, Alger BE (1994) Differences between presynaptic and postsynaptic $\mathrm{GABA}_{\mathrm{B}}$ mechanisms in rat hippocampal pyramidal cells. J Neurophysiol 72:2317-2327.

Poelchen W, Proctor WR, Dunwiddie TV (2000) The in vitro ethanol sensitivity of hippocampal synaptic gamma-aminobutyric acid(A) responses differs in lines of mice and rats genetically selected for behavioral sensitivity or insensitivity to ethanol. J Pharmacol Exp Ther 295:741-746.

Proctor WR, Allan AM, Dunwiddie TV (1992a) Brain region-dependent sensitivity of $\mathrm{GABA}_{\mathrm{A}}$ receptor-mediated responses to modulation by ethanol. Alcohol Clin Exp Res 16:480-489.

Proctor WR, Soldo BL, Allan AM, Dunwiddie TV (1992b) Ethanol enhances synaptically evoked $\mathrm{GABA}_{\mathrm{A}}$ receptor-mediated responses in cerebral cortical neurons in rat brain slices. Brain Res 595:220-227.

Proctor WR, Poelchen W, Bowers BJ, Wehner JM, Messing RO, Dunwiddie TV (2003) Ethanol differentially enhances hippocampal $\mathrm{GABA}_{\mathrm{A}}$ receptor-mediated responses in protein kinase $\mathrm{C}$ gamma ( $\mathrm{PKC}$ gamma) and PKC epsilon null mice. J Pharmacol Exp Ther 305:264-270.

Prosser HM, Gill CH, Hirst WD, Grau E, Robbins M, Calver A, Soffin EM, Farmer CE, Lanneau C, Gray J, Schenck E, Warmerdam BS, Clapham C, Reavill C, Rogers DC, Stean T, Upton N, Humphreys K, Randall A, Gep- pert M, et al. (2001) Epileptogenesis and enhanced prepulse inhibition in GABA(B1)-deficient mice. Mol Cell Neurosci 17:1059-1070.

Roberto M, Madamba SG, Moore SD, Tallent MK, Siggins GR (2003) Ethanol increases GABAergic transmission at both pre- and postsynaptic sites in rat central amygdala neurons. Proc Natl Acad Sci USA 100:2053-2058.

Sanna E, Talani G, Busonero F, Pisu MG, Purdy RH, Serra M, Biggio G (2004) Brain steroidogenesis mediates ethanol modulation of $\mathrm{GABA}_{\mathrm{A}}$ receptor activity in rat hippocampus. J Neurosci 24:6521-6530.

Schuckit MA (1994) Low level of response to alcohol as a predictor of future alcoholism. Am J Psychiatry 151:184-189.

Schuckit MA, Smith TL (1996) An 8-year follow-up of 450 sons of alcoholic and control subjects. Arch Gen Psychiatry 53:202-210.

Sieghart W (1995) Structure and pharmacology of gamma-aminobutyric acid A receptor subtypes. Pharmacol Rev 47:181-234.

Siggins GR, Pittman QJ, French ED (1987) Effects of ethanol on CA1 and CA3 pyramidal cells in the hippocampal slice preparation: an intracellular study. Brain Res 414:22-34.

Sodickson DL, Bean BP (1996) $\mathrm{GABA}_{\mathrm{B}}$ receptor-activated inwardly rectifying potassium current in dissociated hippocampal CA3 neurons. J Neurosci 16:6374-6385.

Soldo BL, Proctor WR, Dunwiddie TV (1994) Ethanol differentially modulates $\mathrm{GABA}_{\mathrm{A}}$ receptor-mediated chloride currents in hippocampal, corti$\mathrm{cal}$, and septal neurons in rat brain slices. Synapse 18:94-103.

Thompson SM (1994) Modulation of inhibitory synaptic transmission in the hippocampus. Prog Neurobiol 42:575-609.

Thompson SM, Gahwiler BH (1992) Comparison of the actions of baclofen at pre- and postsynaptic receptors in the rat hippocampus in vitro. J Physiol (Lond) 451:329-345.

Thomson AM, Destexhe A (1999) Dual intracellular recordings and computational models of slow inhibitory postsynaptic potentials in rat neocortical and hippocampal slices. Neuroscience 92:1193-1215.

Tossman U, Jonsson G, Ungerstedt U (1986) Regional distribution and extracellular levels of amino acids in rat central nervous system. Acta Physiol Scand 127:533-545.

Volpicelli JR (2001) Alcohol abuse and alcoholism: an overview. J Clin Psychiatry 62 [Suppl 20]:4-10.

Wan FJ, Berton F, Madamba SG, Francesconi W, Siggins GR (1996) Low ethanol concentrations enhance GABAergic inhibitory postsynaptic potentials in hippocampal pyramidal neurons only after block of $\mathrm{GABA}_{\mathrm{B}}$ receptors. Proc Natl Acad Sci USA 93:5049-5054.

Weiner JL, Zhang L, Carlen PL (1994) Potentiation of $\mathrm{GABA}_{\mathrm{A}}$-mediated synaptic current by ethanol in hippocampal CA1 neurons: possible role of protein kinase C. J Pharmacol Exp Ther 268:1388-1395.

Weiner JL, Gu C, Dunwiddie TV (1997) Differential ethanol sensitivity of subpopulations of $\mathrm{GABA}_{\mathrm{A}}$ synapses onto rat hippocampal CA1 pyramidal neurons. J Neurophysiol 77:1306-1312.

Williams S, Lacaille JC (1992) $\mathrm{GABA}_{\mathrm{B}}$ receptor-mediated inhibitory postsynaptic potentials evoked by electrical stimulation and by glutamate stimulation of interneurons in stratum lacunosum-moleculare in hippocampal CA1 pyramidal cells in vitro. Synapse 11:249-258. 